\title{
YALE
}

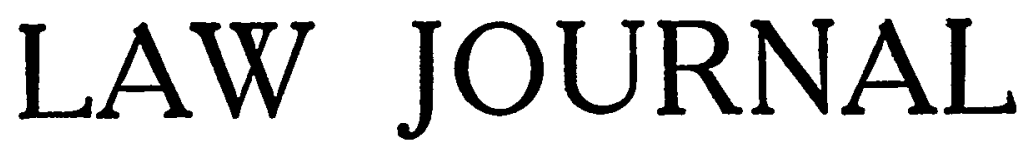

\begin{tabular}{lll}
\hline Vol. XXVIII & MARCH, 1919 & No. 5 \\
\hline \hline
\end{tabular}

\section{THE POWERS OF CONGRESS UNDER THE FULL FAITH AND CREDIT CLAUSE}

\author{
WALTER WHEELER COOK \\ Professor of Law, Yale University
}

We have lived under the present Constitution of the United States for over a century and a quarter. At the end of that long period of time we are still disputing as to what legal effects must or will be given in our states to the "public acts, records and judicial proceedings" of other states. It is still to some extent uncertain when a judgment duly rendered in one state will be recognized as constituting a cause of action ${ }^{1}$ in another state; it is still more uncertain whether many causes of action recognized by the law of one state will also be recognized as such by the law of other states. In short, the

\footnotetext{
${ }^{1}$ Like so many words and phrases in our legal vocabulary, "cause of action" is ambiguous. At times it is used to denote the group of operative facts to which the law attaches legal consequences which enable the person with reference to whom the facts are true to obtain legal relief through a judicial tribunal. As so used the phrase also connotes the legal relations which the law attaches to such a group of facts. At other times, however, the phrase is so used that it denotes the legal relations which result from the facts and connotes that the facts are true of the one who is asserted to have the "cause of action." Codes of civil procedure use the phrase in the former sense when they require a plaintiff to "state the facts constituting his cause of action" in plain and concise language. A common synonym of the phrase as used in the latter sense is "right of action," in which case the word "right" is obviously used in a generic sense and not in the specific sense as the correlative of "duty." Throughout the present discussion an effort has been made by the writer to use the phrase to denote the operative facts rather than the legal relations resulting from them.
} 
"uniform interstate enforcement of vested rights," so forcefully advocated by Mr. Justice Beach of the Connecticut Supreme Court in a recent article in this magazine, is still remote from realization. That the existing condition is desirable, it is believed no one will maintain. Lawyers find it difficult to advise their clients. Litigants all too often find they can not enforce their claims because the wrongdoer is immune from suit in the jurisdiction where he has property subject to execution. To examine into the reasons for this legal anarchy which to a large degree still governs the relations of our states to each other in this respect, and to suggest a means of remedying the situation without a federal constitutional amendment, is the object of the present discussion.

The portion of the Constitution of the United States which bears most immediately upon the problem is the "full faith and credit clause." It reads as follows:

"Full Faith and Credit shall be given in each State to the public Acts, Records, and judicial Proceedings of every other State. And the Congress may by general Laws prescribe the manner in which such Acts, Records and Proceedings shall be proved, and the Effect thereof." ${ }^{18}$

Acting in pursuance of the powers thus vested in it, Congress in I790 provided the mode in which these "public acts, records and judicial proceedings" were to be authenticated, and prescribed their effect in words which have remained substantially unaltered. The present statute reads:

"And the said records and judicial proceedings, so authenticated, shall have such faith and credit given to them in every court within the United States as they have by law or usage in the courts of the State from which they are taken."2

Although the constitutional provision and the Act of Congress seem reasonably plain of meaning at first sight, the slightest examination of the decisions of the courts under them leaves one perplexed and bewildered. What constitutes giving "full faith and credit" in one state to a judgment of another state? To this day no clear answer can be given. As late as 1908 we find the United States Supreme Court divided into the familiar five to four grouping in the leading case of Fauntleroy $v$. Lum. ${ }^{3}$ A recent case in Illinois seems to the present writer identical in substance with Fauntleroy $v$. Lum, yet the Illinois Supreme Court unanimously reached the opposite conclusion. ${ }^{32}$

${ }^{2}$ Art. 4, Sec. I.

${ }^{2}$ U. S. Rev. St. sec. 905 ; U. S. Comp. Stat, I9I6, p. 2431.

(Ig08) 210 U. S. 230, 28 Sup. Ct. 641.

${ }_{2}$ Kenny v. Supreme Lodge, etc., Loyal Order of Moose (1918, I11.) - 120 N. E. 631 . 
In so deciding the Illinois court was fortified by the opinions, if not by the decisions, in cases which were decided before Fauntleroy $v$. Lum. In spite of all the doubt and confusion no attempt has been made by Congress to "prescribe" more clearly the "effect" of state judgments in other states; indeed it seems almost to be overlooked that Congress has power to do so.

That Congress has the power to do far more than it has thus far done seems clear, both from the words of the clause itself and from the history of that clause in the convention which framed the present Constitution. The clause is the lineal descendant of a somewhat similar clause in the Articles of Confederation. That clause read:

"Full faith and credit shall be given in each of these states to the records, acts and judicial proceedings of the courts and magistrates of every other state."

No such clause appeared in the "Virginia" plan for a new constitution submitted by Rando\$ph to the Constitutional Convention of 1787 . As is well known, this plan formed the original basis upon which the Convention worked. On the other hand, it seems clear that the "Pinckney plan," offered by Charles Pinckney, contained a clause substantially identical with that in the Articles of Confederation. ${ }^{5}$ It is also clear that this "Pinckney plan" was referred to the Committee of Detail to whom the report of the Committee of the Whole was referred for elaboration. ${ }^{8}$ The first real appearance of the clause in the Convention's work therefore is in the report of the Committee of Detail. It there reads as follows:

"Article XVI."

"Full faith shall be given in each State to the acts of the Legislatures, and to the records and judicial proceedings of the Courts and Magistrates, of every other State."7

An important change in phraseology from the reading of the clause in the Articles of Confederation should be carefully noted, if we are to grasp the full significance of the clause as it appears in the completed Constitution. Under the Articles of Confederation full faith and credit was to be given only to "the records, acts and judicial proceedings of the courts and magistrates of every other State." The pro-

\footnotetext{
Articles of Confederation, Art. 4.

"The "Pinckney Plan" as printed in Madison's Journal is clearly not the plan actually submitted to the Convention. On the basis of all the available evidence Professor Max Farrand has attempted to reconstruct the plan. As so reconstructed it contains a full faith and credit clause. 3 Farrand, The Records of the Federal Convention, Appendix D, 595-609.

- 2 Farrand, op. cit., ro6.

'Ibid. 188.
} 
vision as reported by the Committee of Detail requires full faith and credit to be given, not only to these but also to "the acts of the Legislatures" of other States. Note however that even yet the clause does not purport to confer upon Congress any power to define by legislation the meaning of "full faith and credit."

When the clause was taken up for discussion it was with other clauses committed to a special committee for reconsideration. ${ }^{8}$ During the debate on the motion to commit the following remarks were made:

"Mr. Madison was for committing . . . He wished the Legislature might be authorized to provide for the execution of judgments in other States, under such regulations as might be expedient. He thought that this might be safely done, and was justified by the nature of the Union.

"Mr. Randolph said there was no instance of one nation executing judgments of the courts of another nation. He moved the following proposition :

'Whenever the act of any state, whether legislative, executive, or judiciary, shall be attested and exemplified under the seal thereof, such attestation and exemplification shall be deemed in other States as full proof of the existence of that act; and its operation shall be binding in every other State, in all cases to which it may relate, and which are within the cognizance and jurisdiction of the State wherein the said act was done." "?

Gouverneur Morris moved to commit also the following proposition on the subject:

"Full faith ought to be given in each state to the public acts, records, and judicial proceedings of every other State; and the Legislature shall by general laws, determine the proof and effect of such acts, records, and proceedings." 10

His motion was adopted. The origin of the provision giving Congress power to prescribe the effect of state "acts, records and judicial proceedings" is therefore to be found in the suggestion of Madison and the proposition of Gouverneur Morris.

When the clause next appears-in the report of the committee to which it had been referred-it is obvious that the suggestions contained in Madison's remarks and Morris' resolution have been acted upon, for the clause now for the first time contains a provision giving Congress powers of legislation. It reads as follows:

\footnotetext{
Ibid. 448.

Ibid. 448.

${ }^{20} \mathrm{Ibid}$. 448. The italics are those of the present writer. It seems obvious that the term "public acts" in Morris's motion is meant to cover public legislative acts.
} 
"Full faith and credit ought to be given in each State to the public acts, records, and judicial proceedings of every other State; and the Legislature shall, by general lazes, prescribe the manner in which such acts, records, and proceedings shall be proved, and the effect which judgments obtained in one State shall have in another."11

As the words in italics show, the power of Congress as the clause then stood would not extend to prescribing the effect in other states of anything but State judgments, but did go that far. Apparently this was intended to cover Madison's suggestion that Congress be given power to provide for the execution of judgments in other states. Apparently also Morris' broader proposition had not met with the Committee's approval. This did not satisfy Morris, for when the clause was taken up for action the following occurred:

"Mr. Gouverneur Morris moved to amend the report concerning the respect to be paid to acts, records, \&c., of one State in other States by striking out, 'judgments obtained in one State shall have in another'; and to insert the word 'thereof' after the word 'effect.'

Col. Mason favored the motion, particularly if the 'effect' was to be restrained to judgments and judicial proceedings.

Mr. Wilson remarked, that if the Legislature were not allowed to declare the effect the provision would amount to nothing more than what now takes place among all independent nations.

Doctor Johnson thought that the amendment, as worded, would authorize the General Legislature to declare the effect of the Legislative acts of one State in another State.

Mr. Randolph considered it as strengthening the general objection against the plan, that its definition of the powers of the Government was so loose as to give it opportunities of usurping all the State powers. He was for not going farther than the Report, which enables the Legislature to provide for the effect of judgments."12

In spite of Randolph's criticism, Morris' motion was carried, as well as a motion to substitute may for shall between the words "Legislature" and "by general laws," and the clause substantially as we now have it was adopted:

"Full faith and credit shall be given in each State to the public acts, records, and judicial proceedings of every other State, and the Legislature may, by general laws, prescribe the manner in which such acts, records and proceedings shall be proved, and the effect thereof."13

What does all this show? Simply that the language of the clause was intended by its framers to give Congress the power "by general laws" to "prescribe the effect," i. e., the legal effects or consequences, in other states of the "public acts, records and judicial proceedings"

${ }^{11}$ Farrand, op. cit., II, 485.

${ }^{13} \mathrm{Ibid} .488$.

${ }^{13}$ Ibid. 489 . 
of a state-including, therefore, legislative acts as well as judgments and all other records and judicial proceedings. It is obvious, that down to the present time Congress has hardly begun to exercise the powers of legislation thus conferred upon it. It has attempted to prescribe the effect of records and judicial proceedings only, and as to those has contented itself with repeating the language of the constitution about "full faith and credit"-language the meaning of which we are still litigating at the end of one hundred and thirty years. Our problem is to determine the extent of the powers of legislation given to Congress but which have been only partially exercised.

Before doing so the writer wishes to direct attention to the method of regulating the same matters in Australia, a country which also has a federal system-modelled in many respects upon our own-but whose constitution was framed at a much later date. As is well known to students of Australian constitutional history, the members of their constitutional conventions made a careful study of our experiences under our Constitution. When framing provisions similar to ours they therefore sought to clear up ambiguities of expression and also to fill in omissions. The result of this study is shown in the following provisions of their constitution:

"Sec. 5I. The Parliament shall have power to make laws with respect to: (xxiv) The service and execution throughout the Commonwealth of the civil and criminal process and the judgments of the courts of the States; (xxv) The recognition of the laws, the public Acts and records, and the judicial proceedings of the States."

"Sec. II8. Full faith and credit shall be given, throughout the Commonwealth, to the laws, the public Acts and records, and the judicial proceedings of every State."

Note that instead of granting legislative power in general terms they have been explicit as to what their federal legislature may do by way of prescribing the effect in other states of judgments, other judicial proceedings, etc., of a state. In pursuance of the clear power thus granted, the Commonwealth Parliament at its very first session enacted the "Service and Execution of Process Act, rgor,"14 amended and brought down to date in I9I2 and known as the "Service and Execution of Process Act, I90I-I912."15 The substance of this legislation ${ }^{16}$ is as follows:

I. The civil and criminal process of each State can be served throughout the Commonwealth. ${ }^{17}$ In the case of civil process, if the defendant does not appear, and it is made to appear to the court from

16 I Commonwealth Acts, I75.

${ }^{25}$ II Commonwealth Acts, 29r.

${ }^{10}$ The complete text is given in Appendix B to this article, p. 44I, infra.

${ }^{17}$ Service and Execution of Process Act, Igor-rgI2, sec. 4 (I). 
which the writ issued, or to a judge thereof, that the writ was personally served, or that reasonable efforts were made to effect personal service on the defendant and that it came to his knowledge, the court may, on the application of the plaintiff, order that the plaintiff shall be at liberty to proceed in the suit, provided it falls within certain enumerated classes. ${ }^{18}$ Obviously it would not be fair to permit a plaintiff to try any suit whatever in any court from which he chose to obtain a writ of summons. The statute therefore enumerates the classes of actions in which it seemed to the Commonwealth Parliament fair to allow him to compel even a non-resident of the state to submit to the jurisdiction of the court.

A discussion of the provisions as to the service of the criminal process of the states throughout the Commonwealth is not within the scope of the present article. They obviously take the place of our somewhat cumbersome and ineffective "interstate rendition" and are much more simple as well as more comprehensive.19

2. A judgment duly rendered in one State may be enforced in other States without suing on it and obtaining a new judgment. This method of enforcing foreign judgments is well known to civil law countries. The statute provides a simple method for registration of the judgment with courts of similar jurisdiction in other states in which execution is desired. ${ }^{20}$ After such registration the judgment has the force and effect of a judgment of the court in which it is so registered. Due provision is made to guard against abuses. ${ }^{21}$ The statute provides for

${ }^{28}$ Ibid. sec. II (I). As the text of the Act is given in the appendix, an enumeration of these classes is omitted here. The provisions of the act in this respect are worthy of careful study.

${ }^{10}$ The inability of our states to obtain interstate rendition of fugitive criminals if the governor of the state in which a criminal is refuses to surrender him is apparently not due to any lack of constitutional power to legislate on the part of Congress, but simply to the fact that the Supreme Court has interpreted the Act of Congress, which says that the surrendering shall be done by the "executive authority" of the state, as "declaratory" and not "mandatory." Commonwealth of Kentucky v. Dennison (1860) 24 How. 66. The Supreme Court in the case cited did indeed seem to take the view that Congress could not make it mandatory upon the chief executive of a state to surrender fugitive criminals. Even if, for the sake of argument, this be admitted, there is a way out of the difficulty, for there seems to be no constitutional objection to an Act of Congress vesting the power to surrender fugitive criminals in the federal judicial officers. This was done in the case of fugitive slaves by the Fugitive Slave Law of 1850 . While the constitutionality of that was attacked, it was finally acquiesced in. The provision for the rendition of escaped slaves and that for the surrender of fugitive criminals use the same language-that the person in question "shall be delivered up"but do not say by whom. It therefore seems to rest with Congress to enact an enforcible interstate rendition law, if it so wishes.

${ }^{\circ}$ Service and Execution of Process Act, rgor-Igr2, secs, 20 and 2I (I).

II Ibid. sec. 2 I (2). 
the registration not only of judgments for money but also for those which either order or forbid the doing of acts.

In accordance with Australian ideas concerning the functions of courts a power to make rules of court to carry into effect the provisions of the statute, both as to the service of process and the enforcement of judgments, is vested in the Supreme Court of each state, or such of the judges as may make rules of court in other cases. We in the United States are not so accustomed as are the Australians to confer upon our courts a rule-making power, but the plan seems to be growing in favor. It is obvious that a power of this kind leaves it open to the highest court in each state to modify the procedural details of the law from time to time as experience demonstrates a necessity for so doing, and thereby gives to the system a flexibility which otherwise it would not possess.

This system has been in force in Australia since Igor and seems to have proved satisfactory, for, as previously stated, it was re-enacted with merely slight improvements in detail in I912. It enables litigants in Australia to enforce their legal rights throughout the Commonwealth with a simplicity and directness unknown to our law.

Can the Congress of the United States without a federal constitutional amendment establish a similar system if it should conclude that such a course is desirable? It is the contention of the present writer that to a large extent this can be done, if a reasonable interpretation is given to the powers of legislation granted to Congress in the full faith and credit clause. To get the problem concretely before us, let us put a series of questions and then attempt to answer them.

If Congress deems it desirable to do so, has it the power to provide:

(I) for the service and execution throughout the United States of the judicial process of the states?

(2) for the enforcement of state judgments throughout the United States?

(3) that a state judgment shall in other states constitute a cause of action upon which suit may be brought and a new judgment obtained, "anything in the constitution or laws of any state to the contrary notwithstanding"?

(4) that where a statute of one state declares that certain facts occurring (in whole or in part) therein shall constitute a cause of action in that state, the same facts shall be recognized in each other state as constituting a cause of action in such other state?

It may be noticed at this point that if questions (I) and (2) are answered in the affirmative and Congress should adopt a law similar to the Australian system, the answers to questions (3) and (4) would become relatively unimportant. If, however, either the power to do the things suggested under (I) and (2) be denied, or it is deemed 
undesirable by Congress to act in pursuance of those powers even if recognized, then, as will perhaps appear more clearly later, the answers to (3) and (4) become of great practical importance.

(I) Service in other states of state process in civil suits. Whether Congress has power under the full faith and credit clause to provide for the direct service in other states of either the civil or criminal process of a state depends upon whether a law so providing would "prescribe" the "effect" in other states of a state "judicial proceeding." Is a writ of summons a "judicial proceeding" within the meaning of the constitution? It is at least a part of a judicial proceeding or a step in one. It can not, of course, be known what the men who framed the clause in question really had in mind; but after all that is not the question, but rather the fair meaning of the words they did use. In passing upon the question we must not overlook the words of Chief Justice Marshall: "We must never forget that it is a constitution that we are expounding." ${ }^{22}$ We may also recall with profit the principle of interpretation laid down by Chief Justice Winsiow of Wisconsin?

"When an eighteenth century constitution forms the charter of liberty of a twentieth century government must its general provisions be construed and interpreted by an eighteenth century mind in the light of eighteenth century conditions and ideals? Clearly not: . . . Where there is no express command or prohibition, but only general language or policy to be considered, the conditions prevailing at the time of its adoption must have their due weight; but the changed social, economic and governmental conditions and ideals of the time, as well as the problems which the changes have produced, must also logically enter into the consideration, and become influential factors in the settlement of problems of construction and interpretation." ${ }^{23}$

Can we not, taking into consideration present day needs, say that the fair meaning, or a fair meaning, of the words used in the clause under consideration includes a power in Congress to provide for the service of state process throughout the states? If the constitutionality of such a law be conceded, we still have to settle its desirability. It is not intended at the present time to discuss this phase of the natter exhaustively, or to urge legislation based upon the view that such a power is vested in Congress. It is the hope of the writer to deal with the matter, both in its constitutional aspects and as a matter of policy, in a discussion to be published later. This much may, however, be said. Our present rules prescribing the jurisdiction in which suit may be brought against a wrongdoer are in many respects arbitrary. We make it depend too much upon whether the defendant can be personally

${ }^{2}$ In $M c C$ ullough v. Maryland (1819) 4 Wheat. $316,40 \%$.

${ }^{23}$ In Borgnis v. Falk Co. (I9II) r47 Wis. 327, 347; I33 N. W. 209, 215. 
served in the jurisdiction in which the suit is brought. According to the law in many states he can, for example, be served in the state where he happens to be, even temporarily, if personal service is effected in that state. This may result in trying the suit in a state in which no part of the operative facts occurred and in which neither of the parties lives. Even if it be tried in the state where the defendant resides, why should a plaintiff, if he gives security for payment of costs, be required to sue an alleged wrongdoer in a jurisdiction where no part of the transaction took place? Is it not more rational to permit him to sue in the jurisdiction where the contract in question was made or to be performed, or in which the tort was committed? Granted that no state can of its own volition make its process run beyond its borders-except as to its own citizens-is it unreasonable that the United States should by federal action be made a unit in the manner suggested? Surely the state in which the operative facts, or some important portion of them, occurred, is an appropriate jurisdiction in which to hear the litigation arising out of them. However, in discussing the desirability of conferring upon state judicial tribunals this broad jurisdiction we must not forget the existence of the federal courts and the power of Congress to extend very greatly their jurisdiction in cases involving diversity of citizenship. Moreover, if state process were to be made to run throughout the country, it would be only natural to adopt similar rules to govern the service of the process of the federal courts.

(2) The direct enforcement of state judgments in other states. From the history of the clause, as well as from its wording, it may be said to be clear that under any fair interpretation of the grant of power to Congress in the full faith and credit clause, that body can provide for the enforcement of state judgments in other states, without the wholly useless and unnecessary process of requiring a new. suit on the same and the obtaining of a new judgment upon which execution can be had. To the mind of the present writer this seems a very obvious way of "prescribing" the "effect" in other states of state judgments. There can of course be no question that a state judgment is both a [judicial] "record" and a "judicial proceeding." Under a properly drawn statute, containing safeguards similar to those found in the Australian statute, such a direct right to obtain execution in other states furnishes a simple and expeditious method by means of which a successful litigant may obtain satisfaction of his claim. That we have so long clung to our more cumbersome system of requiring a new suit merely shows the persistency with which we have adhered to common-law methods without inquiry into their reason for continued existence.

If the proposed law were adopted, it would be necessary to provide that when the judgment of a court of one state is duly registered with a court of similar jurisdiction in another state, the court in which regis- 
tration is effected, or the appropriate officer thereof, shall be under a duty to issue execution. How could this duty be enforced if this officer should refuse to issue the execution? Would the principle involved in Commonwealth of Kentucky $v$. Dennison, ${ }^{24}$ - to the effect that the federal courts can not compel a state governor to render up a fugitive criminal-be applicable? It is believed that it would not be. The Supreme Court of the United States constantly reverses on writ of error the action of the state courts, even the highest, where their action is contrary to federal law. If the state court should refuse to compel the officer in question to do his duty, and the highest state court to which the question could be presented should affirm the lower court's decision, clearly the question could be brought before the United States Supreme Court on writ of error. It is inconceivable that after the federal Supreme Court had once decided in favor of the power of Congress, any state officer would refuse to issue the execution in a proper case. It seems, therefore, that one may conclude that, so far as the second of our questions is concerned, all doubts may be resolved in favor of the power of Congress to take the proposed step.

(3) Compelling states to enforce judgments of other states by rendering new judgments. If we were to provide for the direct enforcement of state judgments in other states, there would be no need for a law requiring the states to recognize that a judgment of another state creates a "debt of record" or similar obligation. If, however, the proposition for direct enforcement of state judgments in other jurisdictions be rejected as too great a departure from our existing system-although why it should be so regarded the present writer finds it difficult to conceive- or if, in spite of the arguments advanced above, the constitutional power of Congress so to provide should be denied, it would still be possible to perfect our present system by clearing up the ambiguities inherent in the federal statute relating to full faith and credit. As already stated, litigation is still going on to determine whether a state must permit suits upon duly rendered judgments of other states. That a state may refuse to entertain such a suit is still the view of many courts and writers. In the opinion of the present writer the present statute ought to be so interpreted as to require the states to enforce judgments of other states by rendering new judgments, thus treating the original judgments as giving rise to debts of record or similar obligations. However, in view of the interpretation given to the present federal statute by at least some state courts it would be desirable-if the simple method of direct enforcement is not adopted-to pass an unambiguous statute clearly making such action mandatory upon the state courts. Of course Congress could in many cases confer jurisdiction upon the federal courts, but

\footnotetext{
${ }^{24}(1860) 24$ How. 66.
} 
there is no reason why the states should not be compelled to open their courts, as was very clearly the intention of the framers of the Constitution. A statute of the kind suggested should in substance provide that a duly rendered judgment of one state must by all other states be treated as constituting a cause of action upon which a new judgment can be obtained. ${ }^{25}$ "Judgment" should be so defined as to include not only judgments for money claims but also injunctions and decrees for specific performance and the like. Would this not be within the power of Congress to prescribe the [legal] effect in other states of state judgments? That it would seems the only reasonable interpretation of the constitutional provision. At the time of the adoption of the Constitution it was the common law that foreign judgments duly. rendered had this effect. Was not the general power vested in Congress to legislate on the matter intended to cover at least a power to make the common-law rule compulsory upon the states, as well as to prevent them in the suit on the judgment from going back of the duly rendered judgment of the other state? If not, it is difficult to see what power it was intended to give to Congress. In the opinion of the present writer the direct enforcement of state judgments in other states upon registration in the latter, as provided in the Australian legislation, would be far simpler and better than requiring new suits to be brought in other states upon such judgments. Nevertheless, to make it clearly compulsory upon the states to render new judgments in such suits would be far preferable to leaving the legal situation in its present condition of uncertainty and doubt.

(4) Compulsory recognition by the states of rights created by legislative acts of other states. Here we enter upon an unexplored field. Down to the present time there seems to have been no discussion of power of Congress to "prescribe" the "effect" [legal consequences] in other states of state legislative acts. It is well settled that under the present Act of Congress in regard to full faith and credit no state is required to recognize as constituting causes of action groups of facts so recognized by the law of other states, even though the operative facts constituting these causes of action, or the more important of them, occurred in these other states. ${ }^{28}$ The matter is left to be regulated by each state, chiefly in accordance with the rules governing the Conflict of Laws, with resulting chaos and confusion, not to

\footnotetext{
${ }^{25}$ Judgments or decrees for divorce might require special provisions. The present writer believes that Congress has power under the clause we are discussing to do much to dispel the confusion which still governs that portion of our law.

${ }^{28}$ The Act of Congress passed in pursuance of the full faith and credit clause attempts to prescribe the effect of judicial records and proceedings only. The text of the Act is printed in the body of this article, supra, p. 422.
} 
say injustice. ${ }^{27}$ If Congress could and would provide in such cases for service in other states of the process of the state where the transaction took place, no necessity would arise for legislation upon this phase of the matter, for judgment could usually be obtained against the wrongdoer in the state where the wrong was committed, and then, under a law providing for the direct enforcement of the judgment in other states, the plaintiff could without suit obtain relief in the state where the wrongdoer had property subject to execution. In the absence of such legislation, and confronted by doubts as to the constitutionality of it-at least so far as provision for the interstate service of state process is concerned-it is well worth while to inquire into the powers of Congress with reference to the enactment of legislation to make compulsory this "interstate enforcement of vested rights" instead of leaving it, as now, to depend upon the whim of the state legislature or the notions of the state court as to the Conflict of Laws. A careful study of the evolution in the Constitutional Convention of the wording of the full faith and credit clause will, it is believed, convince the impartial student that the alteration in the language of the clause to include acts of the state legislatures ("public acts"), and the final shaping of the clause so as to give Congress power to prescribe the effect not only of judgments but also of such public acts, was intended by the more nationally-minded members of the Convention to confer upon Congress some such power. True, we do not know exactly what the members of the convention expected Congress to enact in the way of legislation; but it seems obvious that they were conscious that they were conferring in somewhat general language power on Congress to deal with the matter. If a law of the kind proposed would not "prescribe the effect" of state statutes in other states, what kind of law would? It is difficult to see. If legislation of this kind should at any time be undertaken it would be necessary, in cases in which the operative facts occurred in more than one jurisdiction, to determine very carefully which jurisdiction should have power to determine the legal consequences of such facts. It is conceived that in place of the present chaotic condition which obtains in the field of the Conflict of Laws as applied to interstate relations, Congress

${ }^{27}$ As in the cases where by judicial decision or explicit statutory provision causes of action for wrongful death are refused recognition in states other than the one in which the death was caused. The statute involved in Kenny v. Supreme Lodge, etc., Loyal Order of Moose (Igr8, III.) I20 N. E. 63I, commented upon in (IgI9) 28 YALE LAW JouRNAL, 264, is an excellent example.

There are, however, certain decisions of the United States Supreme Court which seem to point the way even under the present law toward requiring. our states to give effect to statutes of other states. Supreme Council of the Royal Arcanum v. Green (rgr5) 237 U. S. 53I, 35 Sup. Ct. 724, commented upon in (I916) 25 Yale Law Journal, 324; Hartford Life Ins. Co. v. Barber (I9I7) 38 Sup. Ct. 54 . 
could by enacting such a statute substitute, at least to a large extent, a code of uniform national law:.27s The desirability of such a result is obvious. As previously pointed out, however, the need for such a system would be far less if state civil process in appropriate cases could be served throughout the country. For that reason it is not intended at the present time to press the point farther or to advocate legislation of the kind suggested, as the writer hopes ultimately to see provisions for the direct service in other states of state process in appropriate cases.

As indicated above at several points, the present writer does not advocate at the present moment an attempt by Congress to exercise all the powers which a reasonable interpretation of the full faith and credit clause might recognize as vested in that body. A first step toward a simpler system than that which we now have for the interstate enforcement of "vested rights"-a step the constitutionality of which seems reasonably clear-would be the passage of a federal law providing for the direct enforcement in other states, or better in all parts of our country, of judgments validly rendered in any part. To be completely effective the proposed law ought to apply: (a) to all state judgments; (b) to judgments of courts of the District of Columbia and all other portions of the territory subject to the jurisdiction of the United States; (c) to judgments of the federal courts sitting within the states. ${ }^{28}$ Such judgments should be made capable of registration in any portion of the territory subject to the jurisdiction of the United States, whether organized into states or not. ${ }^{29}$ The constitutionality of such a law as applied to judgments of the federal and territorial courts, including those of the District of Columbia, at least so far as it provided for registration with federal courts in other districts or portions of the country, is obvious. It also seems to be well recognized that by virtue of the grant of judicial power in Article III of the constitution and of the power to make all laws "necessary and proper" to carry out the powers vested in the federal Government, Congress may by law require the state courts to give full faith and credit to judgments of federal courts of all kinds. ${ }^{30}$

Any statute of this kind must of course make due provision to pro-

\footnotetext{
${ }^{2 \pi}$ The limitation would be that Congress has power to prescribe the effect of state statutes only, and not that of state "common law."

${ }^{23}$ Judgments of federal courts under our present system may not be enforced by execution outside the state in which they are rendered.

${ }^{20}$ Some doubts may be raised as to whether the system ought to cover outlying territory-the Philippines, for example. So far as the present writer can see, however, there is no real reason for excluding them.

${ }^{80}$ Embry v. Palmer (1883) I07 U. S. 3, 2 Sup. Ct. 25; Atchison, Topeka \& Santa Fe R. v. Sowers (1909) 213 U. S. 55, 29 Sup. Ct. 397; Hancock Bank v. Farnum (Ig00) I76 U. S. 640, 20 Sup. Ct. 506.
} 
tect the defendant from abuse of the power so given. The Australian statute has provisions intended to accomplish this purpose. The holder of the judgment is required to file affidavits that the defendant has not performed the duty imposed by the judgment. ${ }^{31}$ The court in which registration is effected is given the same control and jurisdiction over the judgment as if the judgment were its own judgment, and may on the application of the person against whom the judgment runs order a stay of proceedings on such terms as to security, etc., as may seem to it advisable. ${ }^{32}$ Due provision is made to secure the giving of notice to the court which rendered the judgment and to all courts with which it may have been registered, of all proceedings taken in any court of registration. ${ }^{33}$ The judges of the highest court in each state are also given a rule-making power to prescribe both details of practice and procedure and the fees and costs which shall be paid. ${ }^{8 *}$

In an appendix ${ }^{35}$ will be found a tentative draft of a law along the lines proposed. This draft is offered merely as a suggestion of the kind of statute which ought to be adopted. Criticisms and suggestions will be welcomed by the author.

Can any real reason be given for continuing to follow the commonlaw rule that before the judgment of another American - not foreignjurisdiction can be enforced, a new suit must be brought, with all the attendant expense and delay? In any event the judgment of the sister state is sued upon as a "debt of record," and the "record" is entitled to "full faith and credit." To be sure, within limits it may be attacked upon the ground that the court rendering it had no "jurisdiction" and that therefore it is not really a judgment, or for "fraud" of certain kinds-but under the proposed system the same thing could be done by suitable proceedings in the court of registration or by other appropriate action. It is believed that the proposed law would greatly simplify the enforcement of judgments throughout our country and thereby lessen the expense to litigants and the demands upon the time of our overworked courts. Is it too much to hope that some such simplification may in the near future commend itself to the good sense of the legal profession?

\footnotetext{
"Service and Execution of Process Act, I90I-1912, sec. 23.

2 Ibid. secs. 24 and 25 .

Ibid. sec. 26 .

Ibid. sec. 27.

See Appendix A, p. 436, infra.
} 


\section{APPENDIX A}

TENTATIVE DRAFT OF AN ACT TO PROVIDE FOR THE ENFORCEMENT OF JUDGMENTS THROUGHOUT THE UNITED STATES

An Act to provide for the Execution throughout the United States of the Judgments of the Courts of Record of the States and of the United States and all territory subject to the jurisdiction of the United States, and for other purposes connected therewith.

Be it enacted, etc., as follows:

\section{PART I-PRELIMINARY}

Section I-This Act may be cited as the Execution of Judgments Act, 19-, and is divided into parts as follows:

Part I-Preliminary

Part II-Enforcement of Judgments

Part III-Rules and Regulations

Schedule.

Secrion 2-(I) [A repealing clause, covering all laws inconsistent with the Act.]

(2) This repeal shall not affect any right, privilege, obligation, or liability acquired, accrued, or incurred under any Act so repealed, or affect any legal proceeding or remedy in respect of any such right, privilege, obligation, or liability; and any such legal proceeding or remedy may be instituted, continued or enforced as if this Act had not been passed.

Sectron 3-In this Act unless the contrary intention appears-

(a) "Suit" means any suit or action or original proceeding between parties or in rem;

(b) "Court of Record" includes any court which is required to keep a record of its proceedings;

(c) "Person" includes not only natural persons but also the United States, or a State, or any firm or corporation or other group of persons treated by the law as capable of suing or being sued;

(d) "Plaintiff" means any person seeking relief in a suit against any other person; 
(e) "Defendant" means any person against whom relief is sought in a suit or who is required to attend the proceedings in an action as a party thereto;

(f) "Judgment" includes any judgment, decree, rule or order given or made by a Court in any suit whereby any sum of money is made payable, or the doing or not doing of any act or thing other than the payment of money is required.

PART II-ENFORCEMENT OF JUDGMENTS

SeCtion 4-Any person in whose favor a judgment is given or made, whether before or after this Act takes effect, in a suit in any Court of Record of any State, or any other Court of Record in the United States or any territory subject to the jurisdiction of the United States, may obtain from the Clerk, or other proper officer, of any such Court a certificate of such judgment in the form and containing the particulars set forth in the Schedule hereto or as near thereto as the circumstances will permit, which certificate such officer is hereby authorized and required to grant under his hand and under the seal of such Court, if there be a seal. Such certificate shall contain a statement signed by the Judge, Chief Justice or Presiding Justice of such Court, certifying to the correctness of the certificate.

SECTION 5-(I) Upon production of such certificate-

(a) to the Clerk, or other proper officer, of any other Court of like jurisdiction in any other State, or in any territory subject to the jurisdiction of the United States; or

(b) if there is no Court of like jurisdiction in such State or territory, then to the Clerk, or other proper officer, of such Court as may be designated by rules adopted by the Judges of the highest Appellate Court of such State or territory,

such officer shall forthwith register the same by entering the particulars thereof in a book kept by such officer and to be called "The United States Register of Judgments."

(2) From the date of registration the certificate shall be a record of the Court in which it is registered and shall, for the purpose of the issuance of execution or other process for enforcement, have the same force and effect as a judgment of that Court, and the like proceedings for enforcement may be taken upon the certificate as if the judgment had been a judgment of that Court, and interest shall be payable thereunder at the rate and from the date set 
out therein. Such certificate shall have the same faith and credit in the Court in which it is registered as the original judgment has by the law or usage of the Court in which it was rendered.

(3) No certificate of a judgment shall be so registered after a lapse of 12 months from the date of the judgment, unless leave in that behalf has first been obtained from the Court in which the certificate is proposed to be registered, or from a Judge thereof. Proceedings to enforce a duly registered certificate shall be barred at the time at which the enforcement of the original judgment is barred by the law of the state in which it was rendered.

Section 6-(I) The Court in which any such certificate of a judgment has been registered may, upon being satisfied that registration of the judgment was reasonably justified under the circumstances, order that the plaintiff's costs of registration and other proceedings under this Act, to an amount to be assessed by the Court or Judge, but not exceeding the amount prescribed by the rules of Court hereinafter provided for, be paid by the defendant to the plaintiff.

(2) Any such order shall have the same effect as though it were in the certificate.

SeCtron 7-No execution shall be issued or other proceedings taken upon such certificate unless an affidavit is first filed in the Court out of which it is intended to issue such execution or take such proceedings, made by the person in whose favor the judgment was given or made by some other person cognizant of the facts of the case, stating-

(a) that the amount for which execution is proposed to be issued is actually due and unpaid; or

(b) that an act ordered to be done remains undone; or

(c) that the person ordered to forbear from doing an act has disobeyed the order,

and no execution shall be issued for a larger amount than that sworn to.

Section 8-The Court in which any such certificate of a judgment has been registered and the Judges thereof shall, in respect of execution upon the certificate and the enforcement of the judgment, have the same control and jurisdiction over the judgment as if the judgment were a judgment of such Court.

Sectron 9-(I) The Court in which any such certificate of a judgment has been registered or a Judge thereof may, on the application of any person against whom the judgment has been given or made, order a stay of proceedings on such certificate.

(2) Such order may be made on such terms as to 
giving security, or as to making application to the Court by which the judgment was given or made, to set aside the same, or otherwise, as to the Court or Judge may seem fit.

Section ro-(I) When-

(a) any certificate of a judgment is registered in any Court; or

(b) any execution is issued or other proceedings are taken in any Court upon such certificate; or

(c) satisfaction of the judgment either in whole or in part is entered in any Court upon any such certificate;

the Clerk or other proper officer of that Court shall forthwith notify the same in writing under the seal of the Court to the Clerk or other proper officer of the Court in which the judgment was given or made.

(2) When any judgment whereof a certificate has been registered in any Court has been satisfied in whole or in part, the Clerk or other proper officer of the Court in which the judgment was given or made shall forthwith, upon such satisfaction being made or notified as the case may be, enter such satisfaction upon the judgment and notify such satisfaction, in writing, under the seal of the Court, to the Clerk or other proper officer of every other Court in which a certificate of the judgment has been registered, and such satisfaction shall thereupon be entered upon every such certificate.

\section{PART III-RULES AND REGULATIONS}

Section II-(I) The Judges of the highest Appellate Court of any jurisdiction in the Courts of which under the provisions of this Act the certificate may be registered, or such of them as may make rules in other cases, may make rules-

(a) prescribing the practice and procedure in connection with the execution and enforcement by such Courts of the judgments of the Courts of other jurisdictions whose judgments may be registered under the provisions of this Act;

(b) prescribing the fees to be paid in connection with the registration and the execution and enforcement of such judgments, and the costs to be allowed to any person upon registering and enforcing any such judgment, which fees and costs may be recovered in the same manner as any money payable under the judgment. 


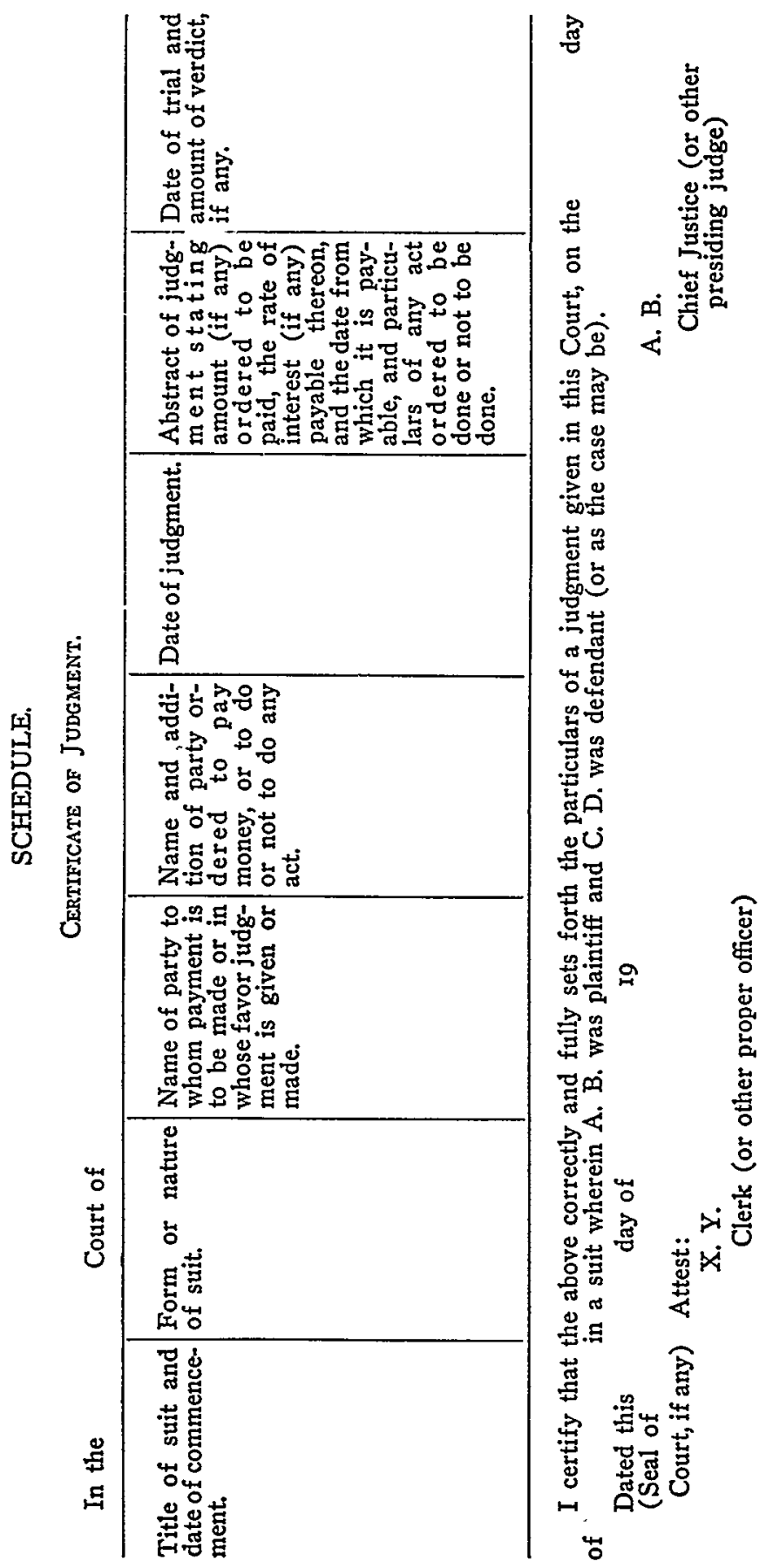




\section{APPENDIX B}

THE AUSTRALIAN SERVICE AND EXECUTION OF PROCESS ACT, IgOI-I9I2

An Act to provide for the Service and Execution throughout the Commonwealth of the Civil and Criminal Process and the Judgments of the Courts of the States and of other parts of the Commonwealth, and for other purposes connected therewith.

Be it enacted by the King's Most Excellent Majesty, the Senate and the House of Representatives of the Commonwealth of Australia, as follows:-

PART 1.-PRELIMINARY.

$\mathrm{I}$-This Act may be cited as the Service and Execution of Process Act Igor and is divided into Parts as follows:-

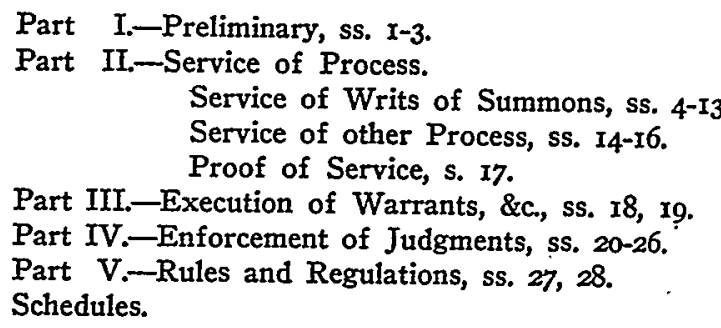

2-(I) The Acts of the Federal Council of Australasia mentioned in the First Schedule hereto, so far as the same may be in force in any State, are hereby repealed.

(2) This repeal shall not affect any right, privilege, obligation, or liability acquired, accrued, or incurred under any Act so repealed, or affect any legal proceeding or remedy in respect of any such right, privilege, obligation, or liability; and any such legal proceeding or remedy may be instituted, continued, or enforced as if this Act had not been passed.

3-In this Act unless the contrary attention appears-

(a) "Suit" means any suit, action or original proceeding between parties or in rem;

(b) "Writ of summons" includes any writ or process by which a suit is commenced or of which the object is to require the appearance of any person against whom relief is sought in a suit or who is interested in resisting such relief;

(c) "Court" includes any Judge or Justice of the Peace acting judicially;

(d) "Court of Record" includes any Court which is required to keep a record of its proceedings;

(e) "Party" includes the Commonwealth or a State or any person suing or being sued on behalf of the Commonwealth or a State;

(f) "Plaintiff" includes the King or any person suing on behalf of the King and any party seeking relief in a suit against any other party;

(g) "Defendant" includes any party against whom relief is sought in a suit or who is required to attend the proceedings in an action as a party thereto; 
(h) "Judgment" includes any judgment decree rule or order given or made by a Court in any suit whereby any sum of money is made payable or any person is required to do or not to do any act or thing other than the payment of money.

PART II.-SERVICE OF PROCESS.

Service of Writs of Summons.

4-(I) A writ of summons issued out of or requiring the defendant to appear at any Court of Record of a State or part of the Commonwealth may be served on the defendant in any other State or part of the Commonwealth.

(2) Such service may, subject to any Rules of Court which may be made under this Act, be effected in the same manner as if the writ were served on the defendant in the State or part of the Commonwealth in which the writ was issued.

5-(I) Every writ of summons for service under this Act out of the State or part of the Commonwealth in which it was issued shall, in addition to any other indorsement or notice required by the law of such State or part of the Commonwealth, have indorsed thereon a notice to the following effect (that is to say):-

"This summons [or as the case may be] is to be served out of the State [or as the case may be] of and in the State [or as the case inay be] of

(2) Every such writ of summons to which, by the law of such State or part, an appearance is required to be entered, shall have endorsed thereon a notice to the following effect (that is to say):-

"Your appearance to this summons [or as the case may be] must give an address at some place within five miles of the office of the Court of at notices for you may be left."

(3) Every writ of summons for service under this Act shall also contain or have indorsed thereon or annexed thereto a short statement of the nature of the claim made or the relief sought by the plaintiff in the suit, and if the plaintiff sues in a representative capacity shall also state such capacity.

6-If a writ of summons or copy thereof does not bear all the indorsements hereby required it shall be ineffective for service under this Act.

7-A writ of summons for service out of the State or part of the Commonwealth in which it was issued may be issued as a concurrent writ with one for service within such State or part of the Commonwealth and shall in that case be marked as concurrent.

8-The time to be limited by the writ of summons for appearance being entered or made by the defendant shall be such as may be prescribed by the Rules of the Court out of which it is issued, but shall not be less than the following, that is to say:-[Here follow special provisions for different portions of the country.]

$9-(\mathrm{I})$ Every appearance entered by or on behalf of a defendant to a writ of summons served on him under this Act shall give an address at some place within five miles of the office of the Court out of which the writ was issued, at which address all proceedings and notices may be left for him.

(2) If such address is not given or is fictitious or illusory the appearance may be set aside as irregular. 
ro-Any defendant who has been served under this Act with a writ of summons may apply to the Court out of which the writ was issued, or a Judge thereof, for an order compelling the plaintiff to give security for costs, and upon such application the Court or Judge may make the order.

II-(I) When no appearance is entered or made by a defendant to a writ of summons served on him under this Act, if it is made to appear to the Court from which the writ was issued or a Judge thereof-

(a) that the subject-matter of the suit, so far as it concerns such defendant is-

(I) land or other property situate or being within the State or part of the Commonwealth in which the writ was issued; or

(2) shares or stock of a corporation or company having its principal place of business within that State or part; or

(3) any deed, will, document, or thing affecting any such land, shares, stock, or property; or

(b) that any contract in respect of which relief is sought in the suit against such defendant by way of enforcing, rescinding, dissolving, annulling, or otherwise affecting such contract, or by way of recovering damages or other remedy against such defendant for a breach thereof, was made or entered into within that State or part; or

(c) that the relief sought against the defendant is in respect of a breach, within that State or part, of a contract wherever made; or

(d) that any act or thing sought to be restrained or removed, or for which damages are sought to be recovered, was done or is to be done or is situate within that State or part; or

(e) that at the time when the liability sought to be enforced against the defendant arose he was within that state or part; or

(f) that the domicile of the person against whom any relief is sought in a matrimonial cause is within that State or part;

and if it is also made to appear to such Court or Judge-

(g) that the writ was personally served on the defendant; or in the case of a corporation served on its principal officer or manager or secretary within the State or part in which service is effected; or

(h) that reasonable efforts were made to effect personal service thereof on the defendant, and that it came to his knowledge or in the case of a corporation, that it came to the knowledge of such officer as aforesaid (in which case it shall be deemed to have been served on the defendant);

such Court or Judge may on the application of the plaintiff order from time to time that the plaintiff shall be at liberty to proceed in the suit in such manner and subject to such conditions as such Court or Judge may deem fit, and thereupon the plaintiff may proceed in the suit against such defendant accordingly.

(2) Any such order may be rescinded or set aside or amended on the application of the defendant.

I2-When a judgment is given or made against a defendant who has been served with a writ of summons under this Act, such judgment shall have the same force and effect as if the writ had been served on the defendant in the State or part of the Commonwealth in which the writ was issued.

I3-This Part of this Act does not confer on any Court jurisdiction to hear 
or determine any suit which it would not have jurisdiction to hear and determine if the writ of summons had been served within the State or part of the Commonwealth in which the writ was issued.

\section{Service of other Process.}

14-(I) When, in any suit in a Court of Record of a State or part of the Commonwealth, any writ (other than a writ of summons) notice decree or other process is required to be served on any party or person, such writ notice decree or process may be served on such party or person in any other State or part of the Commonwealth.

(2) Such service may, subject to any Rules of Court which may be made under this Act, be effected in the same way, and shall have the same force and effect, as if the service were effected in the State or part of the Commonwealth in which the writ notice decree or process was issued.

(3) Thereupon all such proceedings may be taken as if the writ, notice, decree, or process had been served in the State or part of the Commonwealth in which it was issued.

15-(I) When a summons has been issued, on information upon oath, by any Court or Judge or Police, Stipendiary, or Special Magistrate having jurisdiction in any State or part of a State or part of the Commonwealth, commanding any person-

(a) who is charged with any offence alleged to have been committed in that State or part, whether the offence is indictable or punishable upon summary conviction; or

(b) against whom complaint is made, in that State or part, of his having deserted his wife or child, or left his wife or child without means of support,

to appear and answer the charge or complaint or be dealt with according to law, the summons may be served on that person in any other State or part of the Commonwealth.

(2) Such service may, subject to any Rules of Court or regulations which may be made under this Act, be effected in the same way, and shall have the same force and effect, as if the summons had been served in the State or part of the Commonwealth in which it was issued.

(3) If such person fails to appear at the time and place mentioned in such summons, and it appears to such Court, Judge, or Magistrate that the summons was duly served on the defendant a, sufficient time before the day appointed for the hearing, all such proceedings may be taken as if the summons had been served in the State or part of the Commonwealth in which it was issued.

I6-(I) When a subpœna or summons has been issued by any Court or Judge, or Police, Stipendiary, or Special Magistrate in any State or part of the Commonwealth, requiring any person to appear and give evidence, or to produce books or documents, in any civil or criminal.trial or proceeding, such subpœna or summons may, upon proof that the testimony of such person or the production of such books or documents is necessary in the interests of justice by leave of such Court Judge or Magistrate on such terms as the Court Judge or Magistrate may impose be served on such person in any other State or part of the Commonwealth.

(2) If such person fails to attend at the time and place mentioned in such subpoena or summons, such Court Judge or Magistrate, or any other Police, Stipendiary, or Special Magistrate having jurisdiction in the State or part of the State or part of the Commonwealth in which the subpoena or 
summons was issued may on proof that the subpoena or summons was duly served on such person, and that a reasonable sum was tendered to him for his expenses issue such warrant for the apprehension of such person as such Court Judge or Magistrate might have issued if the subpoena or summons had been served in the State or part of the Commonwealth in which it was issued.

(3) Such warrant may be executed in such other State or part of the Commonwealth in the manner provided in this Act in the case of warrants issued for the apprehension of persons charged with an offence.

\section{Proof of Service.}

I7-When any writ notice decree or other process has under the provisions of this Act been served out of the State or part of the Commonwealth in which it was issued such service may be proved-

(a) by affidavit sworn before any Justice of the Peace having jurisdiction in the State or part of the State or part of the Commonwealth in which such service was effected, or before a Commissioner for Affidavits or Declarations, or Notary Public for that State or part; or

(b) in any manner in which such service might have been proved if it had been effected within the State or part of the Commonwealth in which the writ notice decree or process was issued.

PART III.-EXECUTION OF WARRANTS, ETC. - -

I8-(I) When a warrant has been issued by any Court or Judge or any Justice of the Peace having jurisdiction in any State or part of a State or part of the Commonwealth, for the apprehension or commitment of any person-

(a) who is charged with any offence alleged to have been committed within that State or part, whether the offence is indictable or punishable upon summary conviction; or

(b) against whom an indictment for any such offense has been found or presented; or

(c) against whom complaint has been made, in that State or part, of his having deserted his wife or child or left his wife or child without means of support; or

(d) who has failed to comply with an order made against him in that State or part for the support or maintenance of his wife or child; or

(e) who has disobeyed or failed to comply with an order made in that State or part for the payment of money or for the doing of some act; or

(f) who has failed to pay a fine inflicted by a Court of that State or part,

any Justice of the Peace having jurisdiction in any other State or part of a State or part of the Commonwealth, in or on his way to which that person is or is supposed to be, may on being satisfied that the warrant was issued by that Court or Judge (or in the case of a warrant issued by a Justice of the Peace, upon proof on oath of the signature of the Justice) make an endorsement on the warrant authorizing its execution within that other State or part.

(2) Such indorsement may be in the form or to the effect of the Second Schedule hereto, and shall be sufficient authority to the person bringing 
the warrant, and also to all constables and persons to whom the warrant was originally directed, and also to all constables or other peace officers in such other State or part, to execute the warrant in such other State or part, and to apprehend the person against whom the warrant was issued, and to bring him before a Justice of the Peace having jurisdiction in the State on part of the State or part of the Commonwealth in which the person was apprehended.

(3) Such Justice of the Peace may-

(a) Order the person to be returned to the State or part of the Commonwealth in which the warrant was issued, and for that purpose to be delivered into the custody of the person bringing the warrant, or of the constables and persons to whom the warrant was originally directed or any of them; which order may be made by warrant under the hand of such Justice of the Peace, and may be executed according to its tenor; or

(b) admit the person to bail, on such recognisances as he thinks fit, conditioned to appear at an appointed time and place in the State or part of the Commonwealth in which the warrant was issued and answer the charge or complaint or be dealt with according to law.

(4) Such Justice of the Peace shall for the purposes of this section have the same power to remand the person and admit him to bail as he has in the case of persons apprehended under warrants issued by him; and if it be made to appear to him or to any Judge of the State that the charge is of a trivial nature, or that the application for return has not been made in good faith in the interests of justice, or that for any reason it would be unjust or oppressive to return the person either at all or until the expiration of a certain period, the Justice or Judge may discharge the person either absolutely or on bail, or order that he shall be returned after the expiration of the period named in the order, or may make such other order as he thinks just.

(5) Any Justice of the Peace, having jurisdiction in the State or part in or on his way to which the person against whom the warrant was issued is or is supposed to be, may, before the indorsement of the warrant, issue a provisional warrant for the apprehension of that person, upon such information and under such circumstances as in his opinion justify its issue; and the provisional warrant may be executed accordingly:

Provided that a person arrested under a provisional warrant shall be discharged unless the original warrant is produced and indorsed within a reasonable time.

I9-(I) When a writ of attachment has been issued against any person by a Court of Record of a State or a Judge thereof for a contempt of the Court or disobedience of an order thereof, such writ may-

(a) by leave of a Justice of the High Court be executed in any other State or part of the Commonwealth; or

(b) by leave of a Judge of the Supreme Court of any other State be executed in such other State.

(2) Such leave shall be indorsed on the writ, and shall be sufficient authority to the Marshal and also to the Sheriff of the State or part of a State in which the writ was issued, and also to the Sheriff of the State or part of a State in which the writ is to be executed, and to all other officers named in such indorsement, to apprehend such person and bring him before the Court out of which such writ was issued. 
PART IV.-ENFORCEMENT OF JUDGMENTS.

20-Any person in whose favor a judgment is given or made, whether before or after the commencement of this Act, in a suit by any Court of Record of any State or part of the Commonwealth, may obtain from the prothonotary or registrar or other proper officer of such Court a certificate of such judgment in the form and containing the particulars set forth in the Third Schedule hereto or as near thereto as the circumstances will permit, which certificate such officer is hereby required to grant under his hand and the seal of such Court.

2I-(I) Upon production of such certificate-

(a) to the prothonotary, registrar, or other proper officer of any Court of like jurisdiction in any other State or part of the Commonwealth; or

(b) if there is no Court of like jurisdiction in such other State or part, to the registrar or other proper officer of a District or County Court or other inferior Court of Record having civil jurisdiction in such State or part,

such officer shall forthwith-register the same by entering the particulars thereof in a book to be kept by such officer and to be called "The Australian Register of Judgments."

(2) From the date of registration the certificate shall be a record of the Court in which it is registered, and shall have the same force and effect in all respects as a judgment of that Court, and the like proceedings (including proceedings in bankruptcy or insolvency) may be taken upon the certificate as if the judgment had been a judgment of that Court, and interest shall be payable thereunder at the rate and from the date set out therein.

(3) No certificate of a judgment shall be so registered after the lapse of twelve months from the date of the judgment, unless leave in that behalf has first been obtained from the Court in which the certificate is proposed to be registered or from a Judge thereof.

22-For the purposes of the last preceding section any Court mentioned in any of the following sub-sections shall be deemed to be a Court of like jurisdiction with any other Court mentioned in such sub-section, namely :- [Here follows an enumeration of various groups of courts.]

$22 \mathrm{~A}-(\mathrm{I})$ The Court in which any such certificate of a judgment has been registered may, upon being satisfied that the registration of the judgment was reasonably justified under the circumstances order that the plaintiff's costs of registration and other proceedings under this Act, to an amount to bè assessed by the Court or Judge but not exceeding the amount prescribed, be paid by the defendant to the plaintiff.

(2) Any such order shall be deemed to be incorporated with the certificate, and the amount payable thereunder to be payable under the certificate.

23-No execution shall be issued or other proceedings taken upon such certificate unless an affidavit is first filed in the Court out of which it is intended to issue such execution or take such proceedings made by the person in whose favor the judgment was given or made by some other person cognisant of the facts of the case, stating-

(a) that the amount for which execution is proposed to be issued is actually due and unpaid; or

(b) that an act ordered to be done remains undone; or

(c) that the person ordered to forbear from doing an act has disobeyed the order,

and no execution shall be issued for a larger amount than that sworn to. 
24-The Court in which any such certificate of a judgment has been registered and the judges thereof shall, in respect of execution upon the certificate and the enforcement of the judgment, have the same control and jurisdiction over the judgment as if the judgment were a judgment of such Court.

25-(I) The Court in which any such certificate of a judgment has been registered or a Judge thereof may, on the application of any person against whom the judgment has been given or made, order a stay of proceedings on such certificate.

(2) Such order may be made on such terms as to giving security, or as to making application to the Court by which the judgment was given or made, to set aside the same, or otherwise, as to the Court or Judge may seem fit.

$$
\text { 26-(I) When- }
$$

(a) Any certificate of a judgment is registered in any Court; or

(b) Any execution is issued or other proceedings are taken in any Court upon any such certificate; or

(c) Satisfaction of the judgment either in whole or in part is entered in any Court upon any such certificate;

the Registrar or other proper officer of that Court shall forthwith notify the same in writing under the seal of the Court to the Registrar or other proper officer of the Court in which the judgment was given or made.

(2) When any judgment whereof a certificate has been registered in any Court has been satisfied in whole or in part, the Registrar or other proper officer of the Court in which the judgment was given or made shall forthwith, upon such satisfaction being made or notified as the case may be, enter such satisfaction upon the judgment and notify such satisfaction, in writing, under the seal of the Court, to the Registrar or other proper officer of every other Court in which a certificate of the judgment has been registered, and such satisfaction shall thereupon be entered upon every such certificate.

\section{PART V.-RULES AND REGULATIONS.}

27-(I) The Judges of the Supreme Court of any State, or such of them as may make rules of Court in other cases, may make rules-

(a) for prescribing the practice and procedure in connexion with the service of the process of the Courts of such State under this Act, and the execution and "enforcement by such Courts of the process and judgments of the Courts of other States and parts of the Commonwealth; and

(b) for prescribing the fees to be paid in connexion with the service of the process of the Courts of such State under this Act, and the execution and enforcement by such Courts of the process and judgments of the Courts of other States and parts of the Commonwealth, and the costs to be allowed to any person upon enforcing any such judgment (which fees and costs may be recovered in the same manner as any money payable under the judgment).

(2) Until such rules have been made, and as far as any made do not provide for the circumstances of any particular case, the practice and procedure of the State in which the process is issued or in which the service is effected or the execution is enforced respectively shall apply as far as practicable. 
28-(I) The Governor-General may make regulations for carrying out the provisions of this Act and in particular for further applying the provisions or any of them to the service of the process of the Courts of the territories of the Commonwealth, and for the execution and enforcement by such Courts of the process and judgments of the Courts of the States and of other parts of the Commonwealth.

(2) All such regulations shall be notified in the Gazette, and shall thereupon have the force of law.

(3) All such regulations shall be laid before both Houses of the Parliament within thirty days after the making thereof, if the Parliament be then sitting, and if not then within thirty days after the meeting of the Parliament. 